境友好工程奖、第八届中国土木工程詹天佑大奖及中国施工企业管理协会科学技术创新成果一等奖等诸多国家级重要 奖项。项目设计并成功应用了与 $22 \mathrm{mPC}$ 轨道梁截面尺寸相同的 $24 \mathrm{~m}$ 直线 PC 轨道梁, 首次突破了国外 PC 轨道简支梁设 计跨度不超过 $22 \mathrm{~m}$ 的条件限制, 改善了跨座式单轨交通高架区间景观, 降低了建设成本。

作为一项以人们出行便捷和安全为主要目的的重要轨道交通管理基础, 在重庆轨道交通 3 号线的设计施工过程中, 开创性的在两个预制式的导轨梁之间增加设置了一条维修通道。设备检修维护通道的配置大大的提高了轨道交通系统 技术维护工作的效率, 如果轨道交通列车在运行过程中发生故障, 该通道还具有紧急疏散乘客和铺设电缆的功能。

\title{
3 跨座式单轨道岔技术
}

跨座式单轨道岔是跨座式单轨交通系统中用于实现列车转线、调车需求的一种特殊的机电设备, 主要使用场景为 双线折返、运行区间渡线、运行区间避让、出入运行线和车场线等。

\section{1 关节型道岔}

关节型 (不可挠) 道岔的梁体由数节钢制轨道梁铰接组成, 由台车支撑, 采用电力等动力驱动, 道岔梁一端固定, 转辙时道岔梁整体移动并使道岔梁的活动端与另一条线路轨道梁衔接形成岔道, 转换列车行驶路线。关节型道岔转辙 后道岔梁纵向呈折线状。关节可挠型道岔的梁体由数节钢制轨道梁较接组成, 由台车支撑, 其梁两侧装有导向面板和 稳定面板, 转辙时道岔梁一端固定, 梁整体移动并使梁的活动端与另一条线路轨道梁衔接形成岔道, 转换列车行驶路 线, 转辙时挠曲装置在挠曲电机驱动下, 将导向面板和稳定面板挠曲成设定的曲线面, 能使列车以较高的速度平稳地 通过道岔。道岔梁呈直线时，侧面的导向面板和稳定面板恢复成直线状。

\section{2 整体型道岔}

平移型道岔的梁体通常由直梁和曲梁组成, 道岔锁定时, 道岔梁体相对于轨道梁固定, 列车在其上方通过, 当列 车需要转线时, 道岔的锁定装置先进行解锁, 解锁到位后, 道岔梁在驱动装置的驱动下, 沿着与直梁成 $90^{\circ}$ 方向直线 移动, 形成过渡线与相邻轨道梁对接, 锁定装置锁定到位后, 完成道岔转辙。

\section{3 换梁型道岔}

换梁型道岔由两根道岔梁构成, 道岔梁可以由直梁和曲梁或曲梁和曲梁组成, 梁间通过连杆连接, 由台车支撑, 转辙时道岔梁以各自的转轴为回转中心, 通过驱动装置使道岔梁整体转动, 完成道岔梁的替换, 实现与相邻线路的轨 道梁连接, 从而改变车辆行驶线路。根据列车侧向通过时对过岔速度和舒适度要求, 可设置不同曲线半径的道岔, 并 可根据舒适度要求设置缓和曲线。形状分别对应各自线路所需的线形, 道岔曲梁导向面、稳定面按照所需圆曲线由机 械加工而成, 线形流畅。

\section{4 节能环保更具发展前景}

在城市的轨道交通系统网络的设计施工之前, 必须要充分的考虑到当前建设施工区域的地形地貌情况, 以及轨道 交通系统建设对自然环境和周边居民生活工作的影响, 这些影响的因素必须要在轨道交通系统规划、建造和运营阶段 必须加以科学、严谨的分析论证的。根据轨道交通系统噪音测报告, 当跨座式单轨列车运行时, 距离线路 12 米处的噪 声在 57 到 65 分贝之间。列车停靠站以及列车运行线路的电磁辐射情况符合国家设定的相关法律法规标准, 列车运行 引起的轨道周边的环境振动符合相关要求。通过严谨科学的环境监测和线路运行周边的居民抽样调查的结果表明, 跨 座式单轨列车运行的所有环境指标都符合相关规定的要求。与传统的轨道交通相比, 跨座式单轨交通系统对周边环境 的电磁辐射及噪音影响更小, 因此, 该轨道交通系统的建设不仅可以满足城市的居民正常出行需要, 也带来了显著的 生态环境效益和社会效益, 是未来城市轨道交通发展不可缺少的一个重要成员。

\section{5 结语}

跨座式单轨列车的应用已经经过了较长时间的发展, 取得了非常显著的成就, 这也给跨座式单轨列车的普及和推 广创造了良好的基础, 该行业的从业人员仍需要更好的创新相关技术, 为跨座式单轨列车相关技术的突破和完善做出 贡献。

\section{[参考文献]}

[1]许玉红,刘俊杰, 黄星灿. 跨座式单轨交通限界计算研究 [J]. 铁路技术创新, 2018(06):27-34.

[2]路晓宇, 王新敏. 跨座式单轨交通及其轨道梁结构形式比较研究 [J]. 国防交通工程与技术, 2017 (04) : 20-23.

[3]王美,李盼到, 邱文亮,王新山.跨座式单轨交通桥梁结构体系研究 [J]. 世界桥梁, 2016 (03) : 63-68.

[4]武农, 雷慧锋, 郭锴. 跨座式单轨作为中等规模城市轨道交通模式的适应性分析 [J]. 隧道建设, 2015(07): 623-628.

[5]刘兰华, 李晏良, 伍向阳, 何财松. 跨座式单轨列车运行噪声的预测与分析 [J]. 噪声与振动控制, 2015(01): 93-98.

作者简介: 罗海云 $(1971.12-)$, 男, 1996 年武汉汽车工业大学汽车 (专用车辆), 2014 年重庆大学工商管理, 大学本 科, 管理学学士。任职: 贵州航天职业技术学院, 专职教师, 高工\&副教授, 专业方向汽车设计及制造\&城市轨道交通。 


\title{
路桥工程现场施工管理的难点及应对措施
}

张志勇

山东金路交通实业有限公司，山东潍坊 262700

[摘要]目前，迅速发展的交通行业给人们的出行带来了更多的便利，也加速了区域之间的合作往来，推动了经济社会的高效 率发展, 在这个背景下人们对于道路和桥梁工程项目建设的质量要求也越来越高, 因此, 对于工程项目的施工技术以及施工 现场的监督管理工作也有了更高的标准。因为工程项目建造施工的现实问题, 现场施工的管理工作涉及到非常多的管理要素, 管理难度比较大，也必须要才用更加科学合理、更有针对性的管理手段以有效的提升管理效率和管理质量。 [关键词]路桥工程; 现场施工管理; 难点及应对措施 DOI：10.33142/sca.v3i1.1548 中图分类号：U415.1;U445.1 文献标识码：A

\section{Difficulties and Countermeasures of Site Construction Management in Road and Bridge Projects} ZHANG Zhiyong

Shandong Jinlu Transportation Industry Co., Ltd., Weifang, Shandong, 262700, China

\begin{abstract}
At present, the rapid development of the transportation industry has brought more convenience to people's travel, accelerated the cooperation between regions, and promoted the efficient development of economy and society. In this context, people have higher and higher requirements for the quality of road and bridge construction projects. Therefore, there are higher standards for the construction technology of the project and the supervision and management of the construction site. Because of the practical problems in the construction of engineering projects, the management of site construction involves a lot of management elements, which is difficult to manage. It is also necessary to use more scientific, reasonable and targeted management means to effectively improve the management efficiency and quality.
\end{abstract}

Keywords: road and bridge engineering; site construction management; difficulties and countermeasures

引言

中国综合国力的增强, 带动了基础设施建设的进程, 特别是我国交通运输体系建设可以说是让世界瞩目, 四通八 达的高速公路和城市路网, 加速了运输业的发展, 连接了东西南北的大小城市以及城市中的人们。现代社会对速度和 效率的追求越来越高, 这也给道路和桥梁工程项目的建设提出了更高的标准和要求, 也给工程项目的建造企业以及施 工人员带来了更大的挑战。由于道路和桥梁工程项目的建设质量以及施工水平直接关系到了交通运输的效率、安全。 因此, 在道路和桥梁工程项目的建设阶段, 建筑施工企业必须积极地提高工程项目的施工建设质量, 高标准的完成公 路和桥梁工程项目施工。

1 路桥工程现场施工管理的重要性

我国对于交通行业的建设越来越重视, 交通当中的路桥建设意义重大, 路桥工程对于两岸联系, 经济发展都起到至 关重要的作用。道路桥梁的施工较为复杂, 主要原因在于工程量大, 施工线路较长, 并且施工較容易受到影响, 会因为 一些季节性因素，人为因素，不利条件因素而导致工程不能顺利进行。管理的落实主要基于对于施工技术的全面掌握以 及检测监理水平的提高。这样一来对于道路桥梁施工管理才能有所保障, 对于路桥行业的发展才能起到促进作用 ${ }^{[1]}$ 。

2 路桥工程现场施工的管理重、难点

2. 1 预应力技术应用存在的问题

近年来, 我国在道路桥梁工程项目的建设方面取得了很大的进展, 并且获得了相应的成就。在我国道路桥梁工程 项目建设中, 预应力技术的使用是一个重要的发展, 我国对该项技术的使用也逐渐熟练起来, 但是在具体运用的过程 中，仍然会存在一系列的问题 ${ }^{[2]}$ 。

2. 2 过渡段的质量达不到要求

在建设道路桥梁工程项目的过程中, 过渡段的施工占据着非常重要的位置, 该环节的施工质量可以直接反映出整 个道路桥梁工程项目的建设质量。因此, 施工单位在开展道路桥梁施工作业的过程中, 应该有效把控过渡段的施工质 量。如果过渡段的施工质量无法满足标准要求, 就很有可能引发一系列的故障, 甚至会对人员的生命安全产生威胁。

\section{3 材料质量把控难度大}

施工材料的质量对工程项目的建设质量有着决定性的影响。一旦施工材料的质量不达标, 就会对整个工程项目的应 用带来极为不利的影响, 甚至会出现严重的质量问题, 加剧企业的经济损失, 最终对企业的施工形象产生影响。然而, 